\title{
TINJAUAN FILFASAT DALAM PARIWISATA BUDAYA
}

\author{
Pandu Satriya Hutama ${ }^{1}$, Abul Haris Suryo Negoro 2 \\ 1,2 Jurusan IImu Admnistrasi, Universitas Jember Jawa Timur, Indonesia \\ E-mail: pandu.fisip@unej.ac.id', haris.fisip@unej.ac.id²,
}

\begin{abstract}
Abstrak
Kebudayaan membawa implikasi positif dalam menggali antusiasme motivasi wisatawan untuk melihat dan merasakan budaya asli suatu masyarakat. Dalam aspek lain, pariwisata menjadi katalisator pengembangan dan konservasi kebudayaan. Juga membuka peluang dampak negatif terhadap eksploitasi dan komersialisme budaya. Dalam konteks filsafati, aktivitas kebudayaan suatu masyarakat memiliki seperangkat nilai, norma dan kebiasaan, hasil kebudayaan, mampu memberikan efek manfaat dan melindungi anggotanya, dipertahankan dalam kurun waktu lintas generasi. Pariwisata budaya dalam tinjauan filsafat, menjawab konsepsi suatu unsur budaya masyarakat dalam menciptakan peluang positif, nilai-nilai keunikan dan mencegah tumbuhkembangnya aspek-aspek negatif dari keberadaan aktivitas pariwisata.
\end{abstract}

Kata Kunci: Filsafat; Wisatawan; Pariwisata Budaya

\begin{abstract}
The culture would bring the positive implication in building real enthusiasm motivation of tourist to come, see and feel the genuine culture of local society. However, in the other hand, tourism act as a catalyst in development and its conservancy. It opens opportunity negative effects to exploitation and commercialism of culture. In the Philosophy field, the cultural activity of a community has a set of values, norms and habits, cultural performance, bringing benefits and protect its members, conserve the culture in inter generation. The cultural tourism in the scope of philosophy, it could create a conception in such social's culture value, it has its own uniqueness, and it would preventing the developing of negative impacts through tourism activity.
\end{abstract}

Keyword: Tourism Philosophy; Tourist; Cultural Tourism

\section{Pendahuluan}

Tipologi perpindahan seseorang memiliki seperangkat motivasi pendukung dan ketertarikan serta adanya waktu luang. Yang notabene terpusat pada keinginan untuk belajar menambah wawasan dan pengetahuan pribadi dengan batasan waktu tertentu. Konsensus seperangkat pemikiran tersebut merupakan landasan seseorang melakukan perpindahan diri ke suatu tempat tujuan yaitu melakukan perjalanan wisata. Sedangkan, dalam tipologi perpindahan demi mencari tempat baru, dilandasi aktivitas pariwisata, berorientasi pada aspek finansial dan biaya hidup serta mencari ketenangan.

Dalam tataran pemikiran wisatawan terhadap suatu daerah tujuan, memiliki berbagai aspek pertimbangan yang unik, bersifat interpersonal dan penuh tantangan. Karakter unik wisatawan melakukan perjalanan wisata didasarkan pada sisi kemenarikan daerah tujuan, bahkan pada hal-hal yang bersifat klise dan kecil, namum memiliki peran penting dalam proses pertimbangan dan pengambilan keputusan melakukan perjalanan wisata. Sangat interpersonal meskipun dalam tataran pengambilan informasi dalam perumusan rencana melibatkan berbagai peran penting komunikator dan seperangkat informasi dari berbagai media yang lain. Penuh tantangan, haus pengetahuan serta refleksi harapan dan keinginan wisatawan dihadapkan pada perbedaan motivasi melakukan perjalanan wisata. Memiliki pertimbangan urgensitas dan tingkat kepentingan yang sama, serta tingkat kemampuan finansial yang terbatas namun berbeda destinasi. Berpengaruh dalam pengambilan keputusan memilih destinasi tujuan dalam rangkaian merancang skala prioritas.

Perpindahan seseorang dari satu tempat ke tempat yang lain memiliki dua sifat dan tujuan yang berbeda. Dalam konteks sifat, durasi yang dibutuhkan sebagai bagian proses perpindahan bersifat temporary (sementara) atau permanen. Dengan elemen dasar, yaitu 
berorientasi leisure dan recreation (Hall, 2014), durasi yang dibutuhkan untuk melakukan aktivitas pariwisata sangat terbatas. Namun demikian, aspek keterlibatan dan partisipasi sebagai kunci utama dalam pariwisata modern dewasa ini. Dengan semakin kompleks motivasi dan kebutuhan wisatawan, membangun peluang kompleksitas aktivitas leisure dan recreation dalam durasi waktu yang relatif pendek.

Dalam konteks eksternal, proses pengambilan keputusan melakukan perjalanan wisata tergantung dari tingkat biaya yang akan dikeluarkan selama proses perjalanan wisata. Pencarian informasi yang tepat dan akurat terhadap keseluruhan biaya, baik dalam biaya transportasi, akomodasi dan makan dan minum serta biaya-biaya tidak terduga lainnya. Faktor eksternal juga akan mempengaruhi skala prioritas awal motivasi perjalanan wisata. Aspek ketertarikan terhadap destinasi, baik alam, budaya maupun buatan sering menjadi faktor dominan.

Sebagai bentuk entitas perjalanan wisata, setiap wisatawan memiliki motivasi yang tumbuh dan berkembang seiring dengan intensitas informasi yang diterima tentang suatu destinasi tujuan. Mengingat perjalanan wisata menjadi hal yang pertama dilakukan, dan berpeluang nantinya akan menjadi perjalanan yang ke dua dan seterusnya, atau bahkan perjalanan yang pertama dan terakhir. Aspek interdependensi terkait erat dengan bentuk-bentuk pengalaman yang diinginkan dan aktualisasi penerapan pengalaman yang diperoleh. Korelasi hubungan pengalaman yang diinginkan dengan aktual yang didapatkan berkorelasi erat dengan tingkat kepuasan dalam melakukan perjalanan wisata.

Pada tataran tujuan, yang menjadi latar belakang dan motivasi perpindahan seseorang yaitu mencari pengalaman dengan melihat dan merasakan pengalaman terhadap sesuatu yang "berbeda". Memahami terhadap sesuatu yang lampau, memberikan manfaat pengenalan, menguatkan, validasi, identitas individu dan kelompok, panduan, memperkaya pengetahuan dan keluar dari rutinitas (Lowenthal, 1995). Pengkayaan pengalaman berkontribusi penting menciptakan rangkaian pengalaman yang mengesankan.

Pemaknaan pariwisata tidak sebatas pada upaya mobilisasi, namun dalam rangka pencarian pengalaman bersifat lebih lama dengan mencari tempat yang baru (second home). Unsur budaya unik yang melekat dan terus hidup dalam sebuah komunitas memiliki sensasi tersendiri. Menjadi daya tarik wisatawan untuk memusatkan dan mengalihkan perhatian dalam mencicipi dan terlibat dalam aktivitas budaya. Proses interaksi, berbagi pengalaman menjadi lebih lama dan berkembang. Menghasilkan berbagai seperangkat pengetahuan bagi masyarakat setempat dan wisatawan.

Dalam konteks berbeda, filsafat merupakan pengetahuan metodis, sistematis, dan koheren tentang seluruh kenyataan (Hamersma, 2008, dalam Siswoyo, 2013). Bermakna sebuah sistem untuk panduan kehidupan yang berisi prinsip-prinsip perilaku, kepercayaan, tradisi atau prinsip-prinsip umum dari sebuah subjek atau aktivitas. Sistem yang hidup dalam sebuah bentuk kebudayaan masyarakat yang memberikan manfaat bersama, menjadi panduan dalam aktivitas dalam sebuah komunitas tertentu. Memiliki keunikan dan ciri khas serta norma tertentu yang berorientasi pada akar kehidupan nenek moyang yang adiluhung. Praktek kebudayaan sebagai sebuah aktivitas rutin secara tidak langsung menjadi daya penarik berbagai orang atau wisatawan.

Dalam konteks pengertian filsafat pariwisata, merupakan seperangkat prinsip yang mengindikasikan kepercayaan dan nilai-nilai anggota suatu masyarakat. Sangat terkait dengan bagaimana pariwisata memenuhi kebutuhan populasi di suatu daerah atau negara. Berperan sebagai panduan dalam evaluasi keterlibatan pariwisata dalam aktivitas (Goeldner dan Rritchie, 2009). Pariwisata dengan aspek-aspek budaya membawa berbagai konsekuensi, baik dalam rangkaian aktivitas ekonomi dan sosial masyarakat setempat. Memunculkan anggapan penting dan tingginya nilai strategis aktivitas pariwisata dalam menopang pola-pola kehidupan dalam masyarakat.

Menjadi sebuah wacana bagaimana sebuah budaya mampu menarik wisatawan untuk datang dan berkunjung, secara terus menerus, membangun sistem pertahanan internal kebudayaan dalam menghadapi perkembangan zaman, serta filterisasi dan menganulir faktorfaktor eksternal yang dapat memperkaya khasanah kebudayaan. Serta bagaimana wisatawan mampu memberikan feedback dalam membangun kharakter dan mempengaruhi budaya masyarakat setempat. Esensi khususnya pada tataran kebijaka makro pemanfaatan hasil-hasil kebudayaan dalam konteks ekonomi dan sosial, konservasi dan meningkatkan pola pemikiran praktis, menemukenali bentuk kreativitas dan inovasi masyarakat dalam membangun pariwisata budaya. 


\section{Metode}

Dengan menggunakan metode penelitian deskriptif kualitatif, melakukan studi terkait konektivitas ilmu filsafat dan pariwisata. Dengan tujuan memperoleh informasi motivasi perjalanan wisata budaya dalam hubungannya dengan pemaknaan terhadap pencarian pengalaman baru. Penelusuran terhadap studi filsafat pariwisata menjadi hal yang unik, dengan menelaah berbagai fenomena-fenomena yang berkembang pada aktivitas perjalanan wisata dengan motivasi pariwisata budaya. Dimaksudkan untuk memahami berbagai konteks yang berkembang selama ini terkait motivasi wisatawan, perkembangan kebudayaan dalam suatu masyarakat, pemanfaatan hasil-hasil kebudayaan untuk pariwisata.

\section{Hasil dan Pembahasan}

\section{Pandangan Filosofis terhadap Aktivitas Perjalanan Wisata}

Dalam koteks general, perjalanan wisata dianggap mampu meningkatkan pembelajaran dan membangun kecerdasan, menyediakan peran aktualisasi diri dan membentuk seperangkat ingatan pengalaman serta meningkatkan rasa bersosialisasi. Dalam desertasinya, Sarbini berpendapat bahwa eksploitasi terhadap manusia itu sendiri kedalam berbagai bentuk kepentingan dan tuntutan kehidupan yang dinamis, akan menurunkan tingkat kesegaran, kesehatan, instabilitas emosi dan menurunkan produktivitas (Sarbini, 2013). Perkembangan era industri 4.0 yang sangat kental dengan pengaruh teknologi dalam kehidupan, menuntut peran manusia yang menjadi terpogram dengan waktu dan penuh tekanan kehidupan. Ketidakstabilan dalam memenuhi kebutuhan dasar, menciptakan persoalan krusial internal dalam peningkatan kualitas kehidupan jasmani dan rohani.

Rekreasi dalam masyarakat modern, telah menjadi kebutuhan dasar manusia. Manusia ingin menikmati sesuatu yang berbeda dengan rutinitas keseharian. Kebutuhan dasar manusia salah satunya dapat dipenuhi melalui aktivitas perjalanan wisata. Dapat dikatakan bahwa perkembangan aktivitas perjalanan wisata selama ini, merupakan bagian membangun dan merekonstruksi nilai-nilai yang termarjinalkan dalam kehidupan sehari-hari.

Aristoteles dalam buku Protreptikos - Exhortation to Philosophy, menceritakan tentang Themison, seorang Pangeran Cyprus, yang mengilustrasikan kebahagiaan yang sesungguhnya (Aristotle, 1988 dalam Kosiewicz, 2014). Kebahagiaan yang tercermin dalam bentuk rutinitas rekreasi yang dilakukan secara teratur, dalam suatu tempat atau lokasi yang sama atau berbeda, serta memicu efek ketagihan untuk terus menerus melakukan aktivitas rekreasi. Indikasi perjalanan wisata yang memberikan kesan atau menawarkan pengalaman unik, akan menimbulkan perasaan kebahagiaan atau kesenangan. Dan bentuk pengalaman tidak dapat diterima seseorang dengan hanya berbekal cerita atau dokumentasi orang lain. Namun harus mengunjungi dan merasakan sensasi sendiri melalui serangkaian aktivitas dalam rangka membangun pengalaman tersebut.

Terdapat hubungan erat antara ilmu pengetahuan, filsafat, perjalanan dan aktivitas rekreasi fisik atau disebut dengan filsafat pariwisata (Tatarkiewicz, 2009 dalam Kosiewicz, 2014: 10). Rekreasi fisik atau menempatkan posisi jasmani dan rohani kedalam aktivitas yang penuh kerileksan, bertujuan menambah unsur-unsur baru dalam diri sendiri. Dengan durasi waktu yang relatif singkat, aktivitas rekreasi memiliki rangkaian aktivitas makro namun berdampak mikro. Aktivitas makro rekreasi dilandasi dengan motivasi dasar seseorang dalam merencanakan aktivitas rekreasinya. Dengan semakin banyak rencana aktivitas yang dikerjakan dengan durasi waktu yang singkat, namun dengan tingkat pengeluaran seminimal mungkin.

Pariwisata dengan landasan filosofi yang unik dan general, kontekstual dan sistematis. Pola-pola pemetaan bentuk perjalanan wisata umumnya berlandaskan pada keinginan menggali ilmu pengetahuan baru, dalam masyarakat dengan adat istiadat dan budaya berbeda. Pemaknaan terhadap serapan ilmu pengetahuan terejawantahkan kedalam aktivitas keseharian, baik pada tataran nilai-nilai baru yang positif maupun simplifikasi pola-pola kehidupan yang dilakukan selama ini. Dalam konteks general, bahwa motivasi dasar wisatawan melakukan perjalanan wisata akan terus berkembang seiring dengan pola-pola perjalanan dan kebutuhan yang ingin diraih.

Filosofis tentang pariwisata yang terkait dengan aspek budaya, memiliki tiga hal utama yaitu truth, beauty, dan virtue (Tribe, 2009). Isi suatu bentuk kebenaran, yaitu tentang kenyataan, pengetahuan dan disiplin. Sedangkan unsur kebaikan terdiri dari kemanusiaan, estetika, dan 
kesenian. Unsur tidak nyata terdiri dari etika, nilai, dan pandangan hidup. Aspek kenyataan menjadi modal dasar pengembangan aktivitas pariwisata budaya, bahwa secara faktual suatu masyarakat memiliki konten-konten kebudayaan yang unik. Dalam aspek pengetahuan, bahwa masyarakat berbudaya memiliki seperangkat pengetahuan bersifat tradisional. Sedangkan aspek disiplin mencirikan suatu kebudayaan masyarakat terdiri dari berbagai anggota masyarakat yang mempunyai perhatian serius terhadap efekfivitas waktu.

Filsafat pariwisata budaya menggali sebuah potensi untuk dikengembangkan menjadi pariwisata dalam komunitas. Filsafat berperan sebagai bagian dari proses, aktivitas, dan capaian aktivitas pariwisata. Pada tataran filsafat pariwisata dalam destinasi wisata dan formulasi dukungan kebijakan, visi, dan strategi (Goeldner dan Rritchie, 2009). Menjadi landasan dalam pemikiran dan penentuan kebijakan pada tingkat pemangku kepentingan dalam suatu komunitas terbawah sampai teratas.

\section{Kualitas Pengalaman Pariwisata}

Seperangkat kualitas pengalaman dalam aktivitas pariwisata menjadi tujuan utama filsafat pariwisata. Tinggi rendahnya kualitas pengalaman wisatawan dipengaruhi oleh interaksi antara masyarakat dengan wisatawan. Semakin banyak keuntungan yang diperoleh antarkedua belah pihak dan membentuk pengalaman yang positif. Kualitas pengalaman akan terbangun kuat seiring dengan tingkat kedalaman dan kemauan wisatawan dalam memahami konteks kebudayaan setempat. Dalam aspek penting lainnya, yaitu klasifikasi produk-produk pariwisata, pembagian pasar sasaran dan perspektif wisatawan serta nilai keuntungan ekonomi dari pariwisata (Jennings dan Nickerson, 2006). Nilai-nilai filosofis budaya suatu masyarakat secara otomatis memberikan pandangan berbeda dan penyadaran umum wisatawan. Menciptakan rangkaian sikap wisatawan untuk menghargai dan mengapresiasi kebudayaan masyarakat.

Dalam konteks pariwisata secara umum, apabila dibandingkan dengan wisata alam dan minat khusus, pariwisata budaya memiliki tingkat intensitas tinggi dalam menciptakan pengalaman positif. Kebudayaan mampu membentuk seperangkat pengalaman wisatawan yang menyenangkan. Mulai dari produk hasil kebudayaan, keunikan adat kebiasaan, tampilan kesenian, kostum dan bahasa daerah. Faktor komunikasi memberikan peluang hubungan timbal balik serta memberikan sikap saling pemahaman. Masyarakat akan terus belajar dalam menciptakan bentuk-bentuk jasa berupa pelayanan optimal, sesuai dengan kharakter dan ciri khas budaya setempat. Dengan tujuan menemukenali seberapa besar wisatawan mampu menerima perbedaan jasa yang disediakan oleh masyarakat.

Kualitas pengalaman wisatawan baik langsung maupun tidak langsung akan terbangun melalui siklus komunikasi yang bersifat kecil, intensif atau berulang-ulang dan fleksibel. Meskipun domain kualitas pengalaman adalah gambaran ketercapaian atau melebihi antara harapan atau tujuan dengan realitas kehidupan kebudayaan.

\section{Aspek Sosial Ekonomi Pariwisata Budaya}

Menurut Inskeep (1991), perbedaan utama aspek sosial dan ekonomi antara masyarakat dengan wisatawan, yaitu nilai dasar dan sistem logika. Wisatawan mempunyai latar belakang kebudayaan yang berbeda dengan masyarakat setempat. Nilai-nilai lain berupa kepercayaan terhadap agama, tradisi, adat istiadat, gaya hidup, pola-pola perilaku, cara berpakaian, sensitif terhadap alokasi waktu dan sikap terhadap orang asing (Cooper, et all, 2006). Aspek sosial ekonomi memiliki kontribusi krusial dalam perubahan paradigma masyarakat terhadap wisatawan. Masyarakat memiliki pengharapan lebih besar terhadap kebudayaannya agar diterima oleh wisatawan. Membangun citra positif kebudayaan dalam rangkaian pemanfaatan sekaligus konservasi kebudayaan dalam tataran sosial ekonomi. Mengingat hasil-hasil kebudayaan dapat memberikan sumbangsih positif dalam peningkatan pendapatan ekonomi masyarakat.

Dalam konteks sosial, intensitas pertemuan yang timbul sebagai bentuk konsekuensi aktivitas pariwisata budaya, mampu membangun sikap kebersamaan, gotong royong serta toleransi sesama anggota masyarakat. Menumbuhkembangkan semangat untuk mengidentifikasi kelemahan kebudayaan sendiri, dengan tanpa mengikuti arus perkembangan zaman. Merekonstruksi celah-celah kreativitas dalam kebudayaan dalam membangun eksistensi kebudayaan lintas generasi. Serta memberikan arah tujuan yang jelas terhadap kehidupan bermasyarakat yang berbudaya.

Kemampuan elektabilitas kebudayaan suatu masyarakat agar diterima dan menjadi daya tarik unggulan bagi para wisatawan, dipengaruhi oleh tingkat keunikan nilai-nilai yang melekat 
dalam masyarakat. Unik dan menarik suatu hasil-hasil kebudayaan, akan membangun rasa bangga baik wisatawan maupun bagi masyarakat setempat. Dapat diproyeksikan bahwa rasa bangga berbudaya akan memberikan andil terhadap munculnya bentuk-bentuk pertukaran kebudayaan.

Lao Tzu dan Tao Te Ching memberikan pernyataan bahwa seorang wisatawan yang baik adalah yang tidak mempunyai rencana tetap dan tidak berdasarkan pada saat datang. Secara filsafat, ajaran Tao berisi keserasian dan keharmonisan hidup dengan lingkungannya, mampu membentuk manusia yang penuh keharmonisan (Harjanto dan Lasio, 2019). Dalam konteks motivasi dasar wisatawan melakukan perjalanan wisata yaitu saling mempelajari, berkarya dan berkesenian, antara wisatawan dengan masyarakat setempat. Tidak menutup kemungkinan adanya transfer pengetahuan, dimana wisatawan tersebut menjadi agen kebudayaan masyarakat setempat di negara asal.

Perbedaan antarasubjek dan objek pariwisata membawa arah perkembangan dan eksistensi nilai-nilai budaya dalam masyarakat, yang sangat erat dipengaruhi oleh rutinitas dan intensitas aktivitas pariwisata. Secara general membuka peluang pengkayaan budaya, melalui proses inovasi dan kolaborasi budaya. Namun yang harus diperhatikan, pola-pola hubungan wisatawan dengan masyarakat setempat membawa dampak dan konsekwensi logis, berupa distorsi dan komersialisme kebudayaan tanpa arah dan tujuan yang jelas. Pencitraan kebudayaan yang berujung hanya terbatas pada upaya polarisasi pemenuhan kebutuhan wisatawan.

Sehingga sangat diperlukan implementasi filsafat pariwisata berkarakteristik agar arah perkembangan aspek-aspek budaya masyarakat menjadi terarah dan terstruktur. Menjadi sebuah induksi pemikiran terhadap filsafat pariwisata dalam cara pandang ilmu filsafat terhadap aktivitas perjalanan wisata. Dengan pengertian sebagai filsafati yang mendasarkan pada nilai religious, kemanusiaan, keadilan dan bertanggung jawab (Sarbini, 2013). Filsafat pariwisata tidak hanya terkait dengan rasa penasaran atau keberagaman, namun lebih kepada menjadi saksi terhadap cara pandang orang lain dalam kehidupannya. Tidak berperan marjinal dengan hanya melihat dan mendengar, namun menemukenali makna dibalik nilai-nilai kebudayaan yang terkandung didalamnya. Mempelajari, diimplementasikan dan menjadi gaya hidup baru di masyarakatnya.

\section{Filsafat Pariwisata pada Tataran Kebijakan}

Dengan tingkat perkembangan aktivitas pariwisata budaya, diperlukan peran konsisten dari berbagai unsur yang terlibat. Baik para pemangku kepentingan dari tataran terbawah sampai dengan kepala daerah. Pemahaman terhadap nilai-nilai kebenaran dan pengetahuan tentang pariwisata, mampu merepresentasikan pola-pola kebijakan terstruktur dan berkesinambungan. Filsafat pariwisata memberikan ilustrasi holistik dan menjadi landasan dalam memaknai motivasi pariwisata budaya dengan tingkat urgensitasnya bagi masyarakat.

Resistensi kebudayaan terhadap perkembangan zaman, harus dengan pengecualian dan penuh pertimbangan. Masyarakat sebagai pemilik kebudayaan harus dilibatkan dalam proses pengkajian kebudayaan dalam pariwisata. Kebijakan pariwisata budaya pada tataran makro bersifat sangat sensitif terhadap daya serap masyarakat akan pengetahuan, kecenderungan-kecenderungan dan visi kebudayaannya sendiri. Pemangku kepentingan harus merumuskan sistem pengembangan pariwisata budaya yang representatif dengan kemampuan masyarakat. 


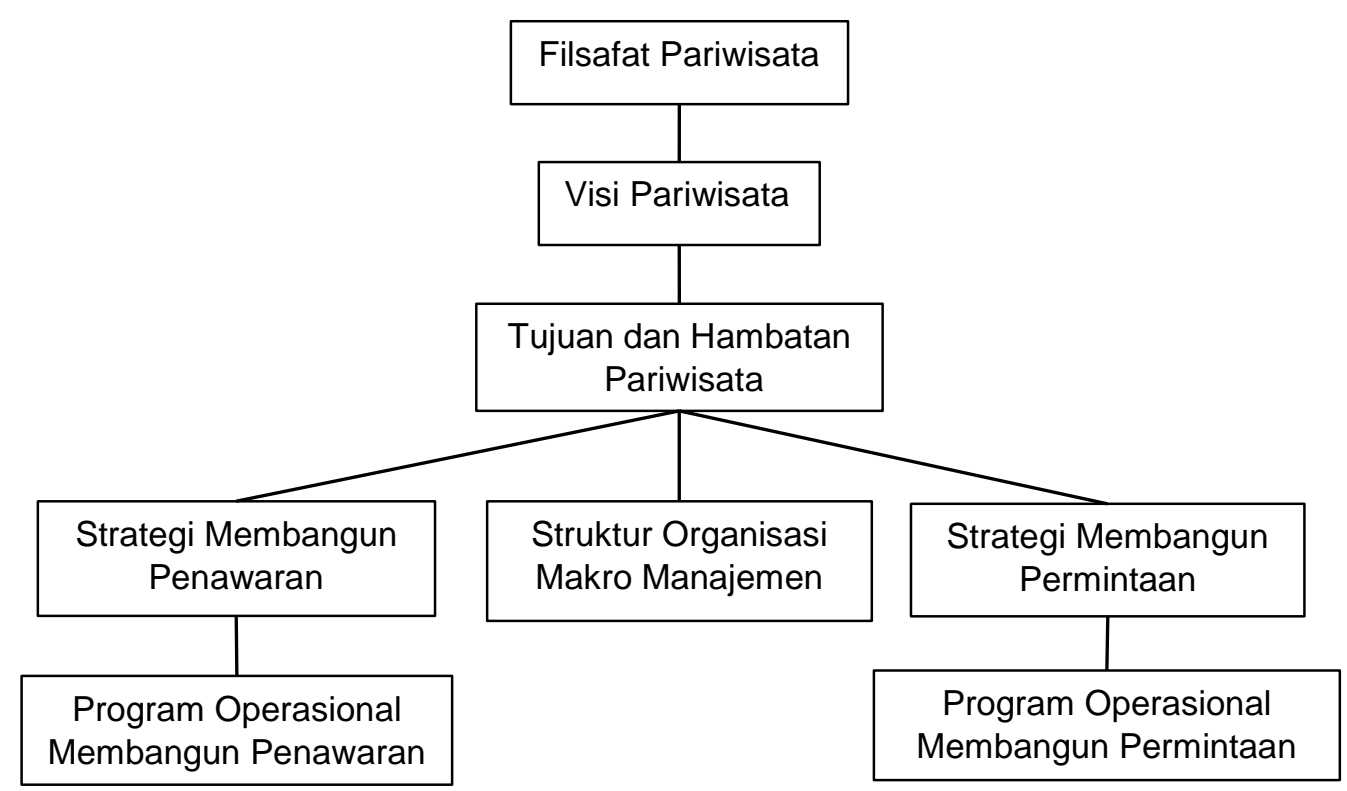

\section{Gambar 1 Kebijakan Level Makro Sosial Ekonomi Destinasi}

Dalam tataran kebijakan makro, pengejawantahan disiplin keilmuan filsafat pariwisata mempengaruhi visi pariwisata suatu daerah. Visi pariwisata daerah terkait pariwisata budaya direpresentasikan dalam rangka konsistensi konservasi kebudayaan daerah dan pola-pola pemanfaatan strategis budaya daerah secara proporsional. Pemangku kepentingan suatu daerah akan dihadapkan pada tujuan dan hambatan-hambatan pariwisata budaya. Identifikasi berbagai kendala pengembangan pariwisata budaya, akan menghasilkan rumusan strategi mengoptimalkan bentuk-bentuk penawaran, mengklasifikasi berbagai jenis permintaan serta membangun struktur organisasi yang mapan. Struktur organisasi yang mumpuni harus berisi sumber daya yang memiliki capaian integritas tinggi terhadap kebudayaan masyarakat. Arah kebijakan harus termotivasi dari kepercayaan terhadap pengembangan dan konservasi budaya daerah demi keberlangsungan aspek sosial budaya lintas generasi.

\section{Simpulan dan Saran}

Dalam konteks filsafat pariwisata, bahwa kedatangan wisatawan ke suatu daerah tujuan wisata budaya dipengaruhi oleh berbagai motivasi mendasar. Rasa keingintahuan dan bertujuan untuk mendalami aspek-aspek kebudayaan suatu masyarakat. Disisi lain, masyarakat memiliki kemampuan dasar dalam menjaga eksistensi kebudayaan sendiri dari berbagai faktor eksternal dan internal yang bersifat destruktif. Masyarakat memiliki kesempatan merubah, menghilangkan, atau menambah hasil-hasil kebudayaan yang dianggap masih lemah. Wisatawan memiliki relevansi dalam berperan menstimulus nilai-nilai kebudayaan yang belum terakomodir dalam kehidupan kebudayaan dalam masyarakat.

Dalam konteks sosial ekonomi kebudayaan, membawa berbagai konsekuensi logis dan praktis bagi peningkatan ekonomi masyarakat. Masyarakat menjadi lebih tergantung terhadap aspek pemanfaatan kebudayaan berbasis ekonomi. Memberikan pemahaman terhadap bentuk komersialisme dan konservasi kebudayaan sebagai dua sisi mata uang. Menstimulus terbangunnya sebuah ritme penyegaran kebudayaan melalui kreativitas dan inovasi anggota masyarakat.

Membangun sistem kebijakan makro pariwisata budaya dengan berlandaskan pada filsafat pariwisata budaya. Mengarahkan pada tataran perumusan strategi-strategi dan sistem manajemen, dalam menghadapi trend perkembangan wisatawan berbasis kebudayaan. Filsafat pariwisata akan menjadi akar dan penyokong pengembangan pariwisata berbasis budaya. 


\section{Daftar Pustaka}

Cooper, Chris; Fletcher, John; Fyall, Alan; Gilbert, David dan Wanhill, Stephen (2006) Tourism: Principles and Practice 3 Ed. Essex: Pearson Education Limited.

Goeldner, Charles R. dan Rritchie, J.R. Brent (2009) Tourism: Principles, Practices, Philosophies. New Jersey: John Wiley \& Sons.

Hall, C. Michael (2014) Second Home Tourism: An International Review. Tourism Internationa Review Journal, Vol. 18. https://www.researchgate.net/publication/267812167_Second_Home_Tourism_An_Internati onal_Review.

Jennings, Gayle dan Nickerson N. P. (2006) Quality Tourism Experiences. Oxford: Elsevier Butterworth Heinemann.

Kosiewicz, Jerzy (2014) Scientific Tourism, Aspects, Religious and Ethics Vvalue. Physical Culture and Sport, Studies and Research Journal, Vol. LXII, Special Issue: Philosophical Studies. $\quad$ https://www.degruyter.com/downloadpdfjpcssr.2014.62.issue-1pcssr-20140014pcssr-2014-0014.pdf.

Harjanto, Rudy dan Lasio (2019) Filsafat Kehidupan dalam Perspektif Tao Tse Ching Lau Tsu.

Lowenthal, David (1995) The Past is a Foreign Country. Cambridge: University of Cambridge.

Sarbini (2013). Pariwisata dalam Perspektif Ilmu Filsafat. Yogyakarta: Universitas Gadjah Mada. https://ugm.ac.id/idnewsPdf8105-teliti-pariwisata-perspektif-ilmu-filsafat-sarbini-raih-doktor http://whytravel.org/topics/philosophy/.

Siswoyo, Sapto (2013) Tourism Philosophy and Policy. Materi Pembelajaran Pengantar Filsafat. Jakarta: Universitas Ciputra.

Tribe, John (2009) Philosophical Issues in Tourism. Bristol: Channer View Publications. 